\title{
島原半島北部沿岸における \\ 流動構造の現地観測 \\ FIELD OBSERVATION ON TIDAL CURRENT STRUCTURE \\ ALONG THE NORTHERN COASTAL AREA OFF SHIMABARA PENINSULA
}

\author{
齋田倫範 ${ }^{1} \cdot$ 矢野真一郎 $^{2} \cdot$ 田井明 ${ }^{3} \cdot$ 橋本泰尚 $^{3} \cdot$ 藤田和夫 ${ }^{4} \cdot$ 小松利光 $^{5}$ \\ Tomonori SAITA, Shinichiro YANO, Akira TAI, Yasunao HASHIMOTO, Kazuo FUJITA \\ and Toshimitsu KOMATSU \\ ${ }^{1}$ 学生会員 工修 九州大学大学院 工学府海洋システム工学専攻( ～812-8581福岡市東区箱崎 6- 10- 1) \\ ${ }^{2}$ 正会員 工博 九州大学大学院助教授 工学研究院環境都市部門(同上) \\ ${ }^{3}$ 学生会員 九州大学大学院 工学府海洋システム工学専攻 (同上) \\ ${ }^{4}$ 正会員 九州大学大学院技官 工学研究院環境都市部門(同上) \\ ${ }^{5}$ フェロー 工博 九州大学大学院教授 工学研究院環境都市部門(同上)
}

\begin{abstract}
Recently, reduction of fish catch and poor harvest of cultured laver in the Ariake Sea have been a serious social problem. It is suspected that construction of the Isahaya Sea-Dyke causes deterioration of aquatic environment in the Ariake Sea. Although several studies on the aquatic environment have ever been carried out, the causes of the deterioration have not been understood clearly. In this study, in order to understand the role of tidal current in the tidal exchange phenomena in northern coastal area off Shimabara Peninsula, in situ measurements on tidal current by ADCP ( Acoustic Doppler Current Profiler ) and sea level by tide gauges were carried out.

As a result of this study, it was observed that the phase of the tidal current near the coast proceeds. It is considered that it is brought about by oscillatory boundary layer. Findings of the present study imply that it is very important to carry out high resolution field observation and numerical simulation in order to understand tidal transport well.
\end{abstract}

key word : Ariake Sea, Isahaya Bay, ADCP, Boundary layer of oscillatory flow

\section{1. はじめに}

有明海はわか泪の代表的な閉鎖性内湾の一つであり， 古くから多樣な生物資源の宝庫として知られてきた。し かし, 1990年以降, タイラギやアサリの漁獲量が咸少し， 2000年冬季に発生した大規模な養殖ノリの色落ちを契機 に, 有明海の水環境問題は大きな社会問題へと発展した . 環境異変の原因の一つとして，1997年4月に潮受堤防の 締切を行った諫早湾干拓事業力指摘されている. 事業主 である農林水産省は，2002年に約8ヶ月間(うち開門期間 (約1ヶ月間)にわたる短期開門調査を実施し，事業は有 明海全体には大きな影響を与えていないと報告 (九州農 政局，2003）したが，2004年8月には，佐賀地方裁判所 力諫早湾干拓工事の差し止めの仮処分を決定した．关の 後, 2005年5月に福岡高等裁判所によって工事差し止め 命令を取り消す決定がさされた。 また，2005年8月には
公害等調整委員会がノリの不作など漁業被害の発生は認 めたが, 科学的なデータ不足などを理由に干拓事業との 因果関係は認定できないとして漁業者らか浗めた原因解 明の申請を棄却する裁定を下した． 兴の一方で, 委員会 はさらなる調査・研究を進め豊かな有明海の再生を念願 するという見解を述べ, 有明海における水環境異変の原 因究明, ならびに水質・底泥環境の保全に向けた取り組 みの必要性を指摘した .

これまでにも国・地方自治体・大学・市民団体などに より, 有明海の水環境悪化の原因究明のための研究が進 められてきている.小松ら ${ }^{1} や$ 生野ら $^{2}$ は, 長崎県有明町 と熊本県長洲町を結亏狭窄部 (以下, 有明一長洲ライン) で, 島原半島沿いに流速が大きくなる非一樣な水平流速 分布を呈していることを報告している.これは, 有明 長洲ラインのすぐ北西側に諫早湾が近接して存在するこ とによるものであり，この水平シアーによって生じる移 
流分散効果力㣺部有明海の海水交換や物質輸送に大きな 役割を果たしていると考えられる。したがって，この有 明 - 長洲ラインおよひ諫早湾口周辺の流動構造を把握す ることは, 有明海およひ諫早湾の海水交換のメカニズム を把握する上で非常に重要であると考えられる．また，

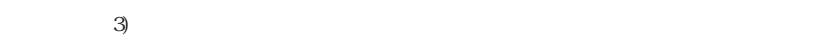
間よりも最大流速の出現する時刻が早くなっており，潮 流に位相差力存在することが示唆されている . 同樣の特 徵は, 諫早湾口南部においても生じていることが中村ら

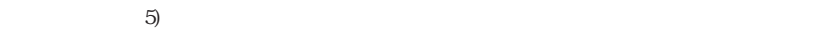
差もこの海域周辺の物質輸送に大きな役割を果たしてい ると考えられる .この現象を現地観測て捉えるためには， 既往の観測よりも時空間的に密な観測が必要である.

乥こで, 本研究では2005年初夏に, 有明一長洲ライン から諫早湾口南部にかけての流動構造およびこの領域で の潮流の位相差を把握することを目的として , 従来より 時空間的に密にADCP 曳航観測を, さらに島原半島沿岸に おける潮位観測を並行して実施したので, 光の結果を報 告する .

\section{2. 観測概要}

\section{(1) ADCP曳航観測}

2005年 7月 7日 (中潮) に, 一潮汐間に渡り計 7 回の ADCP曳航観測を実施した。観測断面は，図一1に示す北部 有明海の海水交換に重要な役割を果たしていると考えら れる有明 - 長洲ラインから, 諫早湾の海水交換に対して 重要な役割を果たしていると考えられる諫早湾口南部ま での計5断面とした . 上げ潮最強時および下げ潮最強時 である1, 4, 7回目は測線 C, S2, S S S4の4断面を, 光 の他の 2, 3, 5, 6回目は測線 SO , S1, S2, S3, S4の5 断 面を観測した .ただし，測線 SOは測線C上にあり，測線 cの始点から約 $3.1 \mathrm{~km}$ までの区間である.観測では2艘(以 下, 観測船 1 , 観測船 2 とする) の観測船が用いられ，航 行速度を5〜 6knot に保ち, DCPSにより測線の確忍を行 いながら，図-1の矢印の向きに断面流速分布を測定した . 観測に使用した ADOPは観測船の対地速度を計測して流速 を補正できるボトムトラッキンク穖能の付いた PDI nstru nents社製 Workhorse ADCP 600ktz，1200ktの計2台で，各々 の設定は表-1のとおりである .

\section{(2) CID観測}

観測時の成層状況を把握することを目的として，ADCP 曳航観測同日の満潮時および干潮時に, 多項目水質計に より塩分と水温の鉛直分布を測定した. 観測点は図-1に 示す ADCP 曳航観測線上の計12地点であり, 各観測点で 船を停止させ , 測点位置は CPSによって確認し, 賠定を 行った . 観測て使用した観測機器は, アレック電子社製 クロロテック AC220およびワイエスアイ・ナノテック社 製YS 6600 である.観測前日に，異なる2つの海域より採

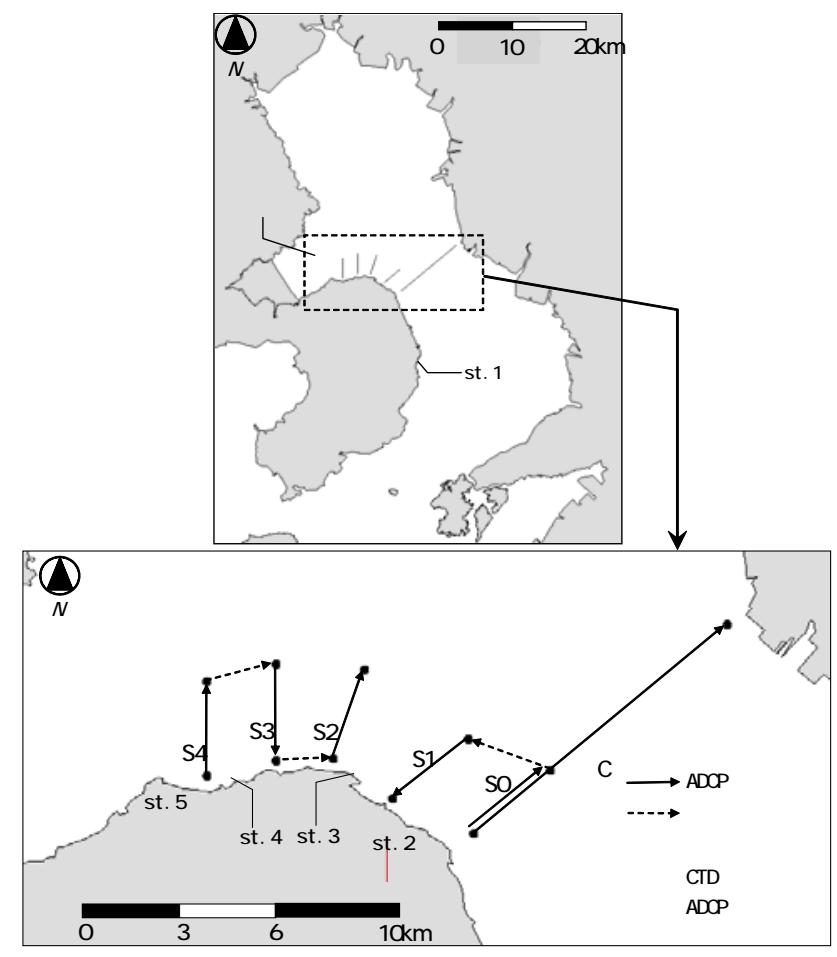

図 - 1 観測実施海域の概略図

\begin{tabular}{c|c|c}
\multicolumn{2}{c}{ 表 - 1 ADCP の設定 } \\
& 観測船1 & 観測船2 \\
\hline 測線 & C, S0, S1 & S2, S3, S4 \\
\hline 観測機器 & ADCP & ADCP \\
& $600 \mathrm{kHz}$ & $1200 \mathrm{kHz}$ \\
\hline 層厚 $(\mathrm{m})$ & 1.0 & 0.5 \\
\hline 表層のブランク $(\mathrm{m})$ & 2.1 & 1.5 \\
\hline サンフリング間隔 $(\mathrm{s})$ & 3 & 2
\end{tabular}

水した海水を用いて測定值の機差を確忍し，データの機 差補正を行った .

\section{(3) 潮位観測}

観測実施海域周辺の時空間的な゙潮位変動を把握するこ とを目的として, 図-1に示す計5点(st.1島原外港, st. 2 有明漁港, st.3: 土黑ひじぐろ)漁港, st.4: 神代(こうじ ろ)漁港, st. 5: 瑞穂漁港)で潮位観測を行った。観測て使 用した観測機器は, アレック電子社製メモリー式水位計 COMPACT- TDで , サンプリング間融を1分に設定した . 観 測期間は6月 1日から 7 月 28日の約2ヶ月間である . 観 測結果について, 各測点での平均潮位を0とし, 各測点 での平均潮位は一致するものとして考察を行った .

\section{3. 観測当日の気象, 潮汐および成層状況について}

アメダス(島原)による観測当日( 5 時〜 20時)の気温は， 23.0〜27.7 Cの範囲にあった . 風は, 早朝は静穏 $10 \mathrm{Ox}$ $\mathrm{s}$ 程度, 昼頃からは南〜南南東の風が $2.0 \sim 4.0 \mathrm{~m} / \mathrm{s}$ 程度 て吹いていた、観測中に降雨はなく，安定した天候・海 象条件の下て観測が行われた .また，7月1日から 7 月 7 


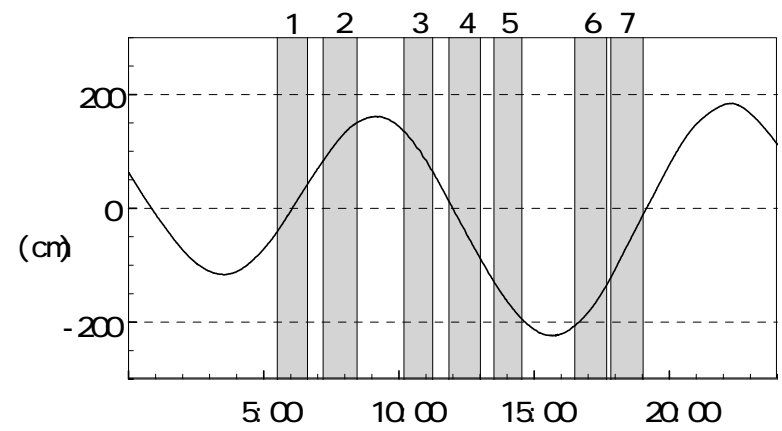

図 - 2 観測当日の潮位 (st 2: 有明漁港)

\section{日までの積算降水量は79nmであつた。}

潮汐の状況について, 潮位観測の結果のうち代表して st.2における潮位の時系列(7月 7日) を図-2に示す .ま た , 図中のハッチ部分はADCP 曳航観測の観測時間帯を， 谷の上の数字は観測番号を表している.この結果より， 実測潮位は干潮: - 111 cnn(3: 27)，満潮: 159cn(9: 07), 干潮:218cn(15: 36)，満潮: 180cn(22 22)であつた .

成層状況について，CTD観測の結果から算出した $\sigma_{t}$ の 断面分布図を図-3に示す.この結果より，満潮時におい て測線 の長洲側の領域では，表層のの值が17.0程度 と比較的低くなっていたが, 干潮時には $\sigma$ の值が220程 度となっていた .このことから，淡水が一時的にこの領 域に偏在していたものと考えられる。実際に，CTD観測 中にこの領域で海色力茶色を呈しているのか確忍された . これは, 九州農政局が 7 月 5 日から 6 日にかけて , 潮受 堤防背後の調整池からの排水力諫早湾に与える影響など を調べるための排水拡散調査を実施した際に，北部排水 門から約 300 万 $\mathrm{t}$ の水を調整池から排水していたことか ら, 光の影響を受けた可能性が考えられる.一方, 乥の 他の海域における表層と底層のの差差は, 満潮時, 干潮 時ともに1.0〜1.5程度であり, 顕著な密度躍層は見ら れなかった .これは, 九州北部では 6月 10日頃に梅雨入 りしていたものの，観測の行われた7月の上旬頃までは カラ梅雨て降水量がかり少なく, 河川からの淡水の流 入が少なかったためであると考えられる .このことから， 密度成層の弱い条件のもとでの観測であったといえる．

\section{4. 流動構造について}

$A D O P$ 曳航観測によって得られた水深平均された水平流 速べクトル図を図-4, 図-5に示す .なお, ADCP曳航観 測では，測線の始点から終点まで測線 SO, S1, S2, S3, S4 では20分程度, 測線Cでは1時間程度の航行時間が必要 であり，同一測線の観測であっても時間的なズレを含ん でる.この結果より，1，4，7回目の測線Cの島原半島 沿いにおいて, 流速力相対的に大きくなって突出してい ることが分かる.上げ朝最強時である1回目と 7 回目の 観測結果を比べてみると，干満差の大きい7回目のほう が兴の傾向がより顕著である .これは, 小松ら ${ }^{3), 1) に よ ~}$
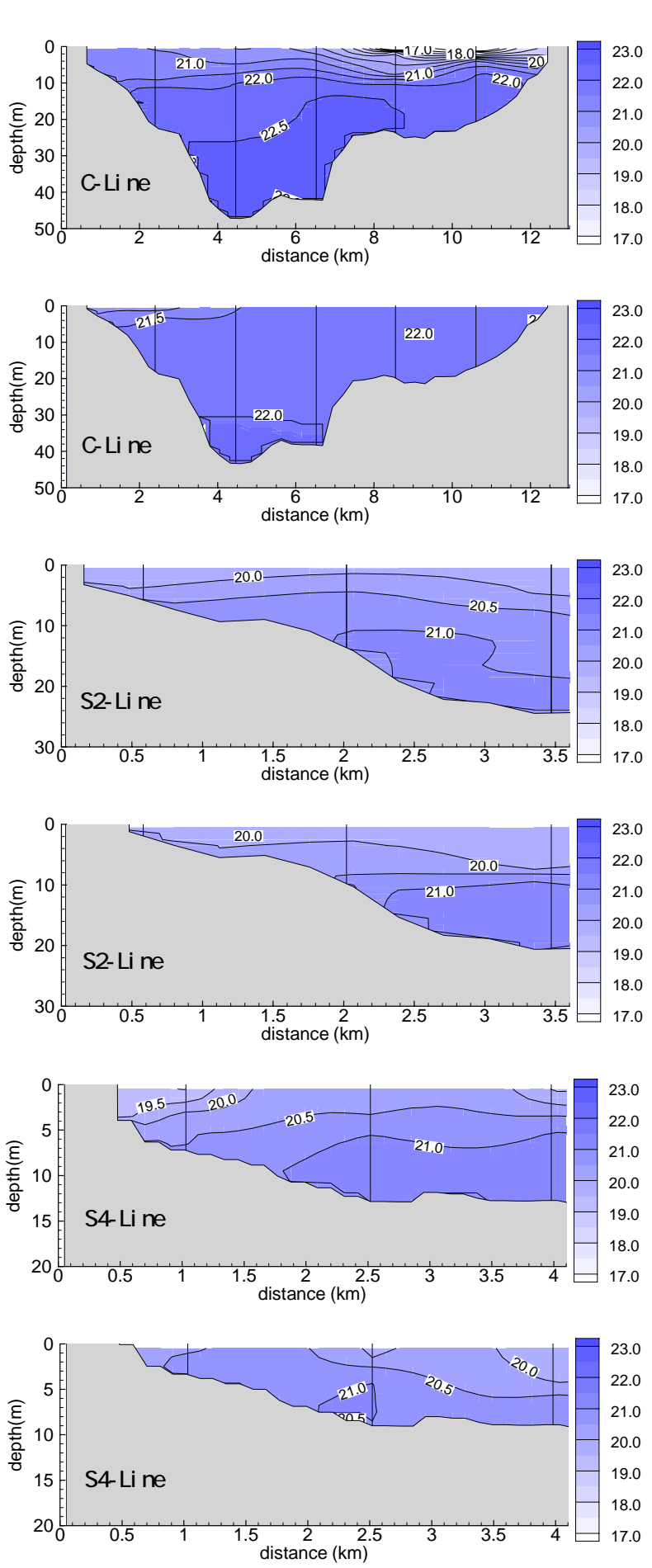

図 - $3 \sigma$ の断面分布図

( 上から, 測線 Cの満潮, 干潮, 測線 S2の満潮, 干潮, 測線 S4の満潮 , 干潮)

る2001年秋季と 2003年夏季の観測結果, および矢野ら 2 による2003年夏季の観測結果においても共通して見られ た特徵である、測線 S2では測線の中央付近で最大流速が 出現しており，特徵的な水平流速分布となっている．ま た，満潮前の 2 回目および干潮前の 5 回目の観測結果に おいて，陸岸近傍ではすで転流力起こり始めており，2

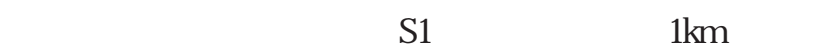




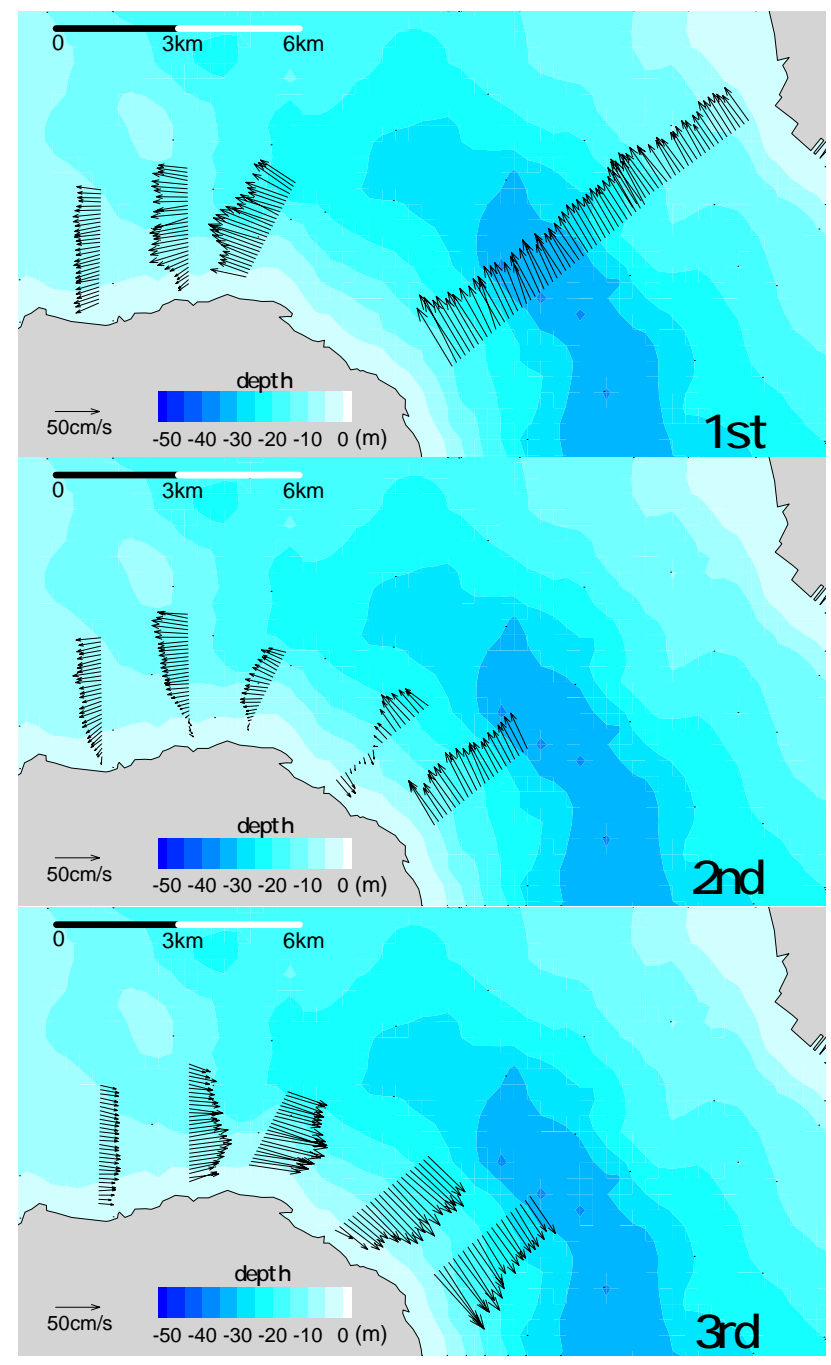

図 - 4 水深平均流速のベクトル図

(上から，1回目，2回目，3回目)

区間では逆流力泩じている。このことから，島原半島沿 岸において, 陸岸近傍の潮流は沖側の潮流に比へて位相 か進んでいると考えられる．乥こで, 陸岸近傍の潮流と 沖側の潮流との間の位相差を把握するために , 各測線上 の3点 (ADOP 曳航観測線の始点から， $0.1 \mathrm{~km}, 1 \mathrm{~km}, 2 \mathrm{~km}$ の 3点)における断面直交成分の流速 $\mathrm{v}$ (湾奥に流入する方向 を正)および水面勾配の時系列を図-6に示す．なお，2つ の潮位観測点における潮位差を 2 点間の直線距離て割つ たものを水面勾配とし, 湾奥方向に海水を流す駆動力と なる湾奥方向へ下がる勾配を正とした . 各測線に対して 対象とする潮位観測点は, 測線 C, SO で 点間の距離: 11 1km，測線 S1では st.2と st.32 $28 \mathrm{~km}$ ，測 線 S2，S3ではst.3と st.4(3.56km)，測線 S4ではst.4と st.5(192km)とした . 縦の破線は水面勾配が0となる時刻 を表す．この結果から，測線 S1の水面勾配が負である 2 回目の観測ては , 測線 $\$ 1020 \mathrm{~km}$ 地点で流速は $325 \mathrm{~cm}$ $\mathrm{s}$ と正であるのに対して , 0.1km地点では流速は- $23.6 \mathrm{~cm}$ sであり，既に転流力堹じていた．また，測線 S1の水面 勾配が正である5回目の観測では，2.0km地点では流速 は-41 2cm/s と負であるのに対して，0.1km地点では流速

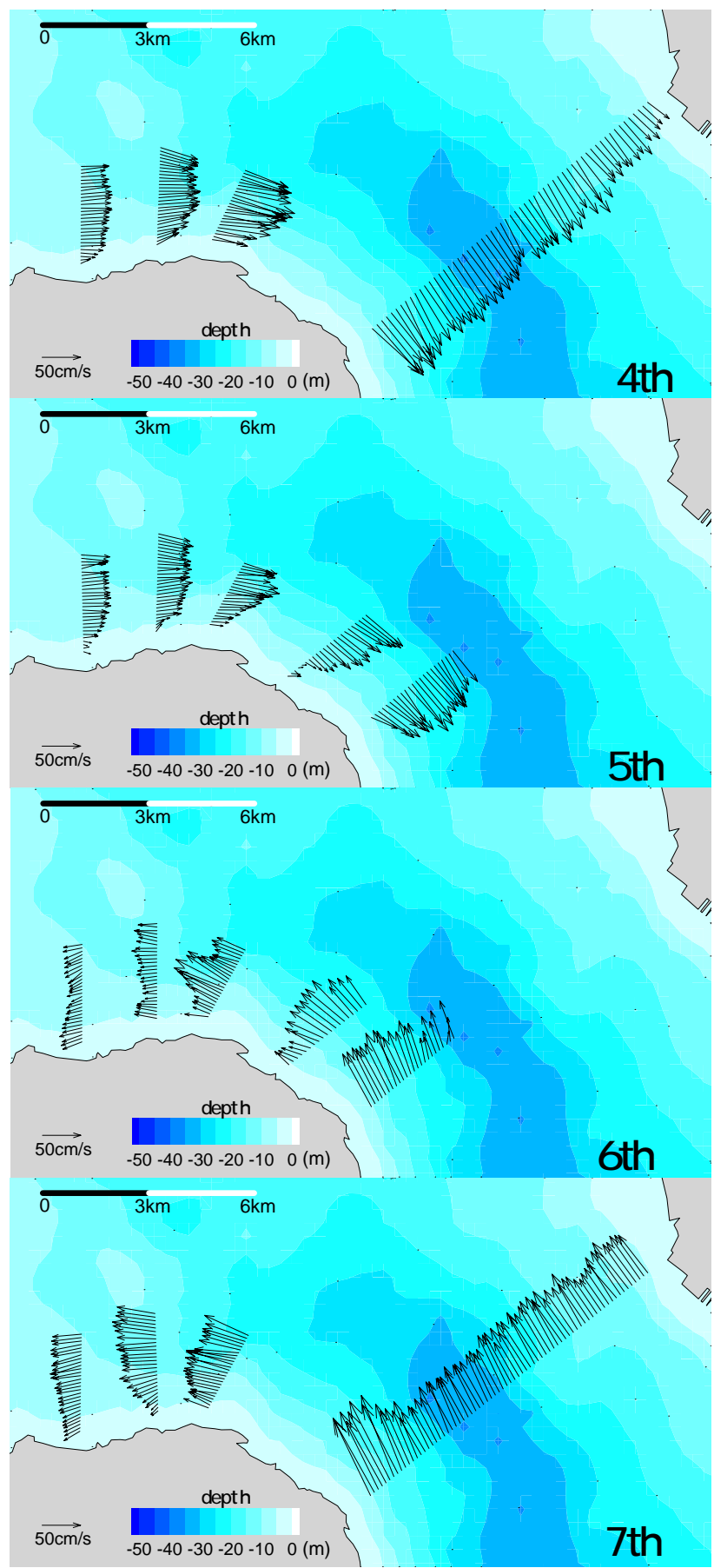

図 - 5 水深平均流速のベクトル図

(上から，4回目，5回目，6回目，7回目)

はほぼ0となっており転流力起こり始めている . 同樣の 傾向は他の測線においても見られており，島原半島沿岸 において陸岸近傍の潮流は沖側の潮流に比べて位相力淮 んでいることか明暸に確認できる．また，測線 S1におい ては, 水面勾配の変動の位相力他の測線と比較して進ん ている，通常，有明海においては副振動の影響によって 定在波的傾向を示すことから，水面勾配は満潮時と干潮 時に大きくなり，潮流の最盛時に水面勾配がほぼOにな る. 測線 SO , S2, S3 周辺では, 概ねこの特徵に対応した 水面勾配泩じていた .一方, 㵋線 S1における水面勾配 は，測線 SO，S2，S3における水面勾配よりも位相力淮ん 

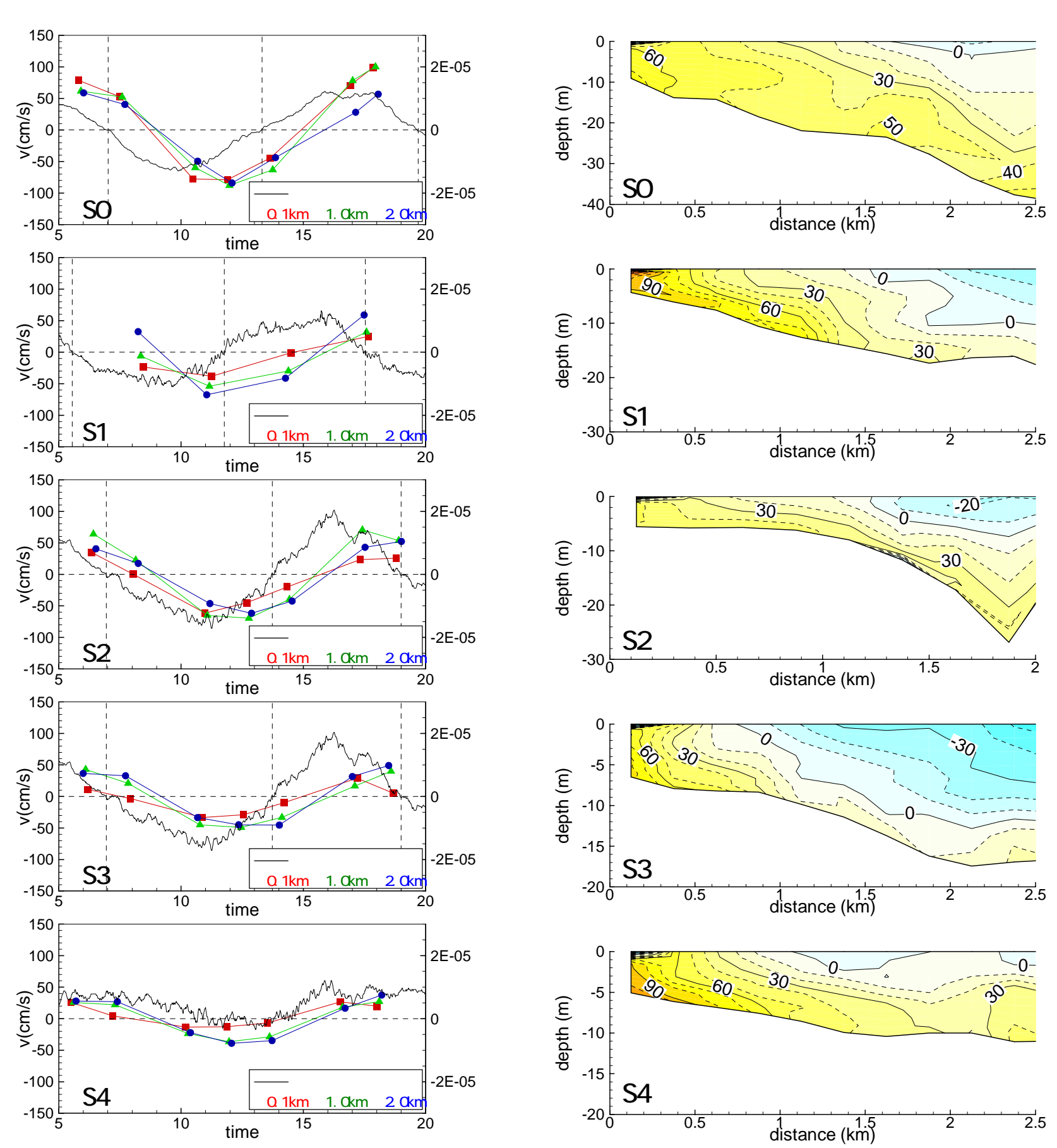

図-6 断面直交成分の流速 $\mathrm{v}$ およ゙゙水面勾配の時系列 (上から，測線 S0，S1，S2，S3，S4)

でることを述べたが，これは上げ朝時と下げ朝時の最 盛時付近に測線 S1 付近で潮流流速を減速させるような水 面勾配力星じていることを示している．2回目の測線 S1 上の観測において確認された陸岸側での逆流は, この空 間的な水面勾配の変動特性によってもたらされたもので あると考えられる .この水面勾配の発生要因について , 陸岸が弯曲していることなどによる二次元的な現象の影 響が考えられ，一次元的な水面勾配の情報からは十分な 検証が行えないことから, 今後, 室内実験や数值シミュ

図-7 土黑( st. 3) における潮位との位相差の断面分布図 (上から，測線 SO $, \mathrm{S} 1 ， \mathrm{~S} 2, \mathrm{S3} ， \mathrm{S4}$ )

レーション等で検討する必要がある.潮位変動と流速の 位相差のさらに詳細な特性を把握するために, 土黑漁港 ( st . 3) の潮位を基準とした場合の潮位変動との位相差の 断面分布図を図-7に示す. 図中の数值の単位は分である. なお，位相差は流速変動と潮位変動を最小二乗法を用い て正弦関数て近似し, 弚れらの位相差として算定した . また, 曳航による観測時刻のズレは船の航行速度を一定 と仮定して補正している。この結果より, 上層の位相に 比べて底層の位相のほうが進んでいることがわかる . 位 
相の進んた領域力゙海底面に沿って分布していることから， これらの現象は海底摩擦による振動流境界層の影響であ ると考えられる。特に，陸岸側では水深が仦さ，位相 の進んでいる層が海面に達しており，これか陸岸沿いの 位相の進んだ潮流の出現要因となっているものと考えら れる。

\section{5. まとめ}

諫早湾口南部から島原半島沿岸にかけての流動構造を 把握するために現地観測を実施した . 得られた結果をま とめると以下のようになる .

1)小松らによって報告されている有明 - 長洲ライン西側 の相対的に大きな流速の突出部分は, 本観測においても 確認された .

2) 島原半島沿岸において , 陸岸近傍の潮流は沖側の潮流 に比べて位相が進んでおり，有明－長洲ライン西側の流 速が大きい潮流部分についても，この特徵を有している . 3) 上層の位相に比へて底層の位相の方が進んでおり，陸 岸側の浅い領域においては, 海底摩擦による振動流境界 層の存在力陸岸沿いの潮流の位相を早める要因となって いるものと考えられる .

4) 測線 S1においては, 海岸地形の影響によって水面勾配 の変動の位相力他の測線よりも進んでいるため, 他の測 線と比較して陸岸側の流速の位相のズレか湿著になった と考えられる

有明海奥部に排出された物質の多くが, 諫早湾を経由 した後に島原半島に沿って南下していくことが, 千葉らの による数值シミュレーションによって確認されている． このことから, 本研究て対象とした諫早湾口南部から島 原半島沿岸にかけての海域は, 赤潮の発生や貧酸素化が 著しい諫早湾および北部有明海の海水交換や物質輸送に 対して重要な役割を果たす海域であると考えられる.本 研究て観測された水平方向の位相差によって生じる非一 樣な水平流速分布は, 移流分散効果をもたらすことに よってこの海域の物質輸送に大きな役割を果たしている .
このことは, 沿岸域の水環境を考える際には, 海域全体 の流況だけではなく, 局所的な゙流況も十分考慮する必要 があることを示唆している、特に, 北部有明海は地形変 化が大きく，光の局所的な地形によって生じる現象を考 慮することは非常に重要である.このことから，局所的 な流況を精度良く把握・再現できる高い空間解像度を 持った現地観測や数值シミュレーションカ強く望まれる.

謝辞: 島原漁協, 有明漁協, 土黑漁協, 神代漁協, 瑞穂 漁協には, 潮位観測に際して水位計係留場所を提供して 頂いた . また，有明漁協の松本正明氏，宮本雄二氏，な らびに篠塚光信氏には, 観測船の傭船に多大な二協力を 頂いた ·ここに記し，深甚なる感謝の意を表する．

\section{参考文献}

1)小松利光, 矢野真一郎, 齋田倫範, 松永信博, 弟鳥奇賢 一, 德永貴久, 押川英夫, 濱田孝治, 橋本彰博, 武田誠, 朝位孝二, 大串浩一郎, 多田彰秀, 西田修三, 千葉賢, 中村武弘, 堤裕昭, 西ノ首英之 : 北部有明海における流 動・成層構造の大規模現地観測, 海岸工学論文集, 第 51 巻, pp. $341-345,2004$.

2) 矢野真一郎, 齋田倫範, 橋本泰尚, 神山泰, 藤田和夫, 小松利光: 有明海における潮汐条件に対する流動・成層 構造の变化, 海岸工学論文集, 第 51巻, pp. 331-335, 2004. 3)小松利光, 安達貴浩, 金納聡, 矢野真一郎, 小橋乃子, 藤田和夫 : 有明海における流れと物質輸送に関する現地 観測, 海岸工学論文集, 第 50巻, pp. 936 -940, 2003.

4) 中村武弘, 矢野真一郎, 多田彰秀, 野中寛之, 龟井雄 一 : 諫早湾湾口部における流況の現地観測, 海岸工学論 文集, 第 49巻, pp. $396-400,2002$

5) 齋田倫範, 矢野真一郎, 橋本泰尚, 小松利光 : 大規模 一斉観測データを用いた諫早湾口周辺の流重牲寺性の検討， 海岸工学論文集, 第 52 巻, 2005

6) 千葉賢, 武本行正 : 諫早湾潮受け堤防設置に伴う有明 海の流況変化に関する研究 : 海岸工学論文集, 第 50 巻, pp. 376380 , 2003

(2005. 9.30 受付) 